\title{
Human Security: A Path to Global Security
}

\author{
Prof Yu Xiaofeng and Imran Ali Sandano \\ (Centre for Non-Traditional Security and Peaceful Development Studies, Zhejiang University, China)
}

\begin{abstract}
The traditional concept of national and international security in essence stay away from war between and avert offensive by other states have, necessarily, been outmoded in recent time. In the post-cold war era "human security" has enormously become significant, mainly since September th 200. The need of human security has become the turning point in the international politics, and human security issues have been accepted both by policy makers and international institutions. A further incorporated approach to studying this field is obligatory to attain the preferred outcome of combined security, i.e from the individual to international level.
\end{abstract}

Keywords: human security; global security; national and international security; approaches to security.

\section{Introduction}

The idea of national and international security has become very old because it's only surrounded by the idea of protecting national interests, the territory and of sovereignty from external threats. International security imitate attention largely on the state level collisions of armed conflicts; once a state is capable to protect its territorial, military, and political interests from external intimidations, it is perceived to have achieved national security.

During the cold war period, realist school of thought dealing with security had strong grip on the foreign policy paradigms and the head of the states used to remain remorselessly engaged with the pursuit of military dominancy. The importance of neo-realist notion on states like the only most significant entities in the international structure directed to the criticism of the interests of people and factions inside states. Individuals without sovereignty did not deserve concentration at the international level, and what happened inside the border of a sovereign did not deserve concentration at the international level, and whatever happened inside the borders of a sovereign state was placed under the state jurisdiction. Merely threats to the existence and security of states were measured as unfavorable to global security and thus admirable of international action and attention.

In bleak difference to this conventional point of view, the rising perception of human security predominantly believes that the security of state population and put immense emphasis on the elements that creates insecurity amongst the people existing inside states are not restricted to continuation of the state. In this observation, the security of people is inextricably bound-up with their quality of life. Threats to peoples' security comprise various economic and social issues afar the territorial integrity of their states. Therefore, as the occurrence of sadistic international conflict can harmfully involve all or any of the elements related with the security of common people, the cessation or absence of armed conflict does not promise the eradication of threats to human security. Problems like disease proliferation and environmental degradation threaten not only the security of people in particular state, but with no trouble can reach at global level.

This study purely designed to evaluate the basic concept of human security and to draw a clear cut picture of interdependence of human security and global security. The Cold War era, changing concept of international security and the result oriented debate among world scholars to foresee challenges to the theoretical and practical framework of human and global security gives more importance to the study. In this debate, the study has tried to give answers of mind boggling questions like, how is human security changing the traditional pattern of international relations and how human security has become the core for maintenance of global security? Before discussing the main theme, there is a need to understand basic concepts of human security.

\section{Liberal Approach}

The advocates of Human security coin their concepts under a fundamental confront towards the longestablished regulations and follow global affairs. The radically divided patterns have motivated the supporters of human security to honestly keep both theory and practice. Meanwhile, there is frequent trend to combine two or more sets of aspiration of human security theorizing with policy making process with authenticity, for instance, it has been stated (Shahrbanou and Anuradha, 2007) state that: 
"With human security [the individual 'qua person', rather than 'qua citizen'] becomes the ultimate actor taken into account. His/her security is the ultimate goal, to which all instruments and political actors are subordinated. Elevating 5the person as the ultimate end is made possible by defining this new actor in terms of his/her vulnerabilities on the one hand, and his/her capacity to affect change on the other.

No doubt, in the real world, no one fellow the "speech act" or "academic assertion" which generates a security discussion. "Individuals qua persons" undoubtedly have divergent and diverging security concerns which make it impossible for ultimate actors, like international organizations which are subordinated. Amartya Sen, (999) recognized that the "human-centered" concept, highlighted in his book, remains involved in collective decision making of political process. The declaration that "individuals qua persons", for example the outside a political process can induce control, creates logical theory, keep away from practice; however, this concept draw attention to the liberal supports' fundamental perceptive of the transformative prospective of human security approach.

The supporters of liberal school of thoughts believe that the concept of human security does not counter-pose the vested interests of post-colonial Western beneficiaries, so called (influential elites). The argument clearly pointing out the interest of Western states, which needs a shift from unenlightened and backward concepts of self interest. It argues that the term 'human security' and the meaning of self-interest has been created by Western elitist class; it is not forced by fundamental confrontational action from outside.

\section{Realist and Post-Realist Approach}

Many analysts, particularly those who are more involved in practical observation of human security expressed logical criticism on the approaches which are recognizing the human security attraction for global players. Few have strongly recommended that there is a slight dissimilarity between traditional approaches of state based security, global based security and the fundamental human security notions. It has been interestingly defined (R Muggah and K Krause, 2006) that it is a developing approach and stated that, "state is informed by what they see as the weakness of 'constructivist / critical International Relations' - the tendency to 'treat discourses as significant themselves, without examining the link to actual practices." In this regard they presented the connection between discourse and practice, and observed the diversities between pre and post human security intrusions. They have significantly evaluated and examined the UN missions in Haiti of $993-$ 995 when there was no perception of human security rambling and the second UN missions in Haiti 2003 2005 created the human security agenda. In such scenario it will be hard move towards the motive of global security.

\section{Human and Global Security}

The concept of human security, subsequently proposes a more precise manifestation of global security than the security of states in the post-cold war period. Obviously, the security of state is necessary for the security of people; though, the state security single-handedly does not ensure human security. For example, the events of 9/and following influence of terrorism have forced governments and international organization to switch their focal point on societies' vulnerabilities ahead of national border security and conventional military power. The study of human security permits (T. Owen 2004) us to know the foundation of common vulnerabilities and useful ways to alleviate them. Furthermore, research findings focused on determinants of human security can illuminate the actual benefits and costs of international and national policies (for instance intervention of involvement in international armed conflict, economic liberalization, and environmental regulations) by approximating their direct priorities on inhabitants of relative population.

The human security as an outline for appraising global and population security was first coined by United Nations Development Programme (UNDP) in Human Development Report of 994, which termed it "profound transition in thinking....for nuclear security to human security." During the cold war period, the idea of security had been restricted to safeguarding national interests, defending territory, and avoiding a global nuclear war; consequently, the concept of global security was intimately connected with the political and territorial security of nation states. Meanwhile, the world powers caught up in the tensions, with the developedstates determining to carry on their ideologies and the newly independent countries protecting themselves against intimidation to their independence. In the scrimmage for military dominancy the troubles of common people who inhabited sovereign states rarely made it on the international affairs schema. Mutually, politics and erudition were controlled by the realist school of thought and its stress on states as the key players in the international political system; what is happening inside the borders of states was granted diminutive concern or attention. Accordingly, the conflicts within states plus the standard of life of individuals were matters downgraded to domestic authority and didn't value the equal apprehension from the international community as inter-state conflicts were dealt with. The (UNDP, 994) report described human security as: 
"For most people, a feeling of insecurity arises more from worries about daily life than from the dread of a cataclysmic world event.....human security is a child who did not die, a disease that did not spread, a job that was not cut, an ethnic tension that did not explode in violence, a dissident who was not silenced. Human security is not a concern with weapons; it is a concern with human life and dignity."

This depiction shows that human security holds two key elements. The first is protection from stable threats (such as poverty and repression) that avert people from getting a suitable living standard. Second, human security is the deficient of unexpected disastrous incidents that disturb the lives of people which includes the natural disasters. The people centric notion of human security is a global; the effects of threats such as terrorism, global warming, crime, food insecurity, drugs tracking, disease proliferation and economic depression are not restricted within any single state. In this observation, the global nature of human security imitates the mutually reliant of international community on each other and therefore the threats of human security are preeminent tool to address at the global level.

The UNDP has categorized human security into seven components: personal security, food security, health security, environmental security, economic security, community security and political security. According to its explanation, a people could only be believed as secure if they enjoy all these seven components of security. Personal security entails the capability of individuals to entertain their lives without any physical threat. Food security involves approach to food at all times for all members of the society. This connotes that the availability of food for purchasing at a reasonable cost and people have the financial means to purchase food that fulfills nourishment requirements. Health security grips access to both curative and preventive healthcare in addition to safeguard from health threats, such as viral diseases. Environmental security involves protection from local and global ecosystem threats. Economic security refers to protect basic income in the course of productive employment. Political security subsists if the civil and human rights of people are valued by their native states and people do not endure political subjugation.

The community security indicates to the protection of groups, assortments from family units to ethnic and minority communities. This debate clearly indicates that human security offered a roadmap for evaluating the security requirements of nations and international communities in the post cold war period. The advocates of the gigantic view of human security are worried about the security of individuals, whereas traditional school of international security studies focuses on the security of states and consider invasion or war as the major security threat. The report (CHC, 2003) 'Human Security Now', argues that human security balances states security by consisting threats that may not essentially involve state security, like the healthcare and human rights issues. It describes a comprehensive approach to human security that enlarged the perception of security from country's territorial borders to the people who are living inside.

According to this report, human security threats comprise illiteracy, ill health, malnutrition and environmental pollution. It focuses on living standard and threats like, hunger, poverty, disease, and illiteracy reveals the significance of development. Mahbub Ul Haq (999) has argued that security can be obtained through development instead of weapons and expects a global and inseparable idea of human security. He argues (Haq 999) that is it "easier, rather than face their tragic consequences downstream."

In the same way, Manab Thakur (997) put emphasis on the significance of the quality of life of people as a key element of human security and view any challenge to their quality of life as a threat to the security of people. Amartya Sen (2000) explains that threats to human security contains any threat to the endurance, standard of living, and human dignity, at the same time Robert Grant McRae (2002) emphasizes on the lives of individuals by appraising the socio-political state of nations. However, Human security can not be merely viewed as an upshot of or escort to development. According to Commission on Human Security report (2003), the response of institutions and states to issues of human security "can not be effective if it comes fragmented (from those dealing with rights, those with security, those with humanitarian concerns and those with development.) With human security as the objective, there must be stronger and more integrated response from communities and states around the globe."

No doubt, human security is usually offered as a principle to global security. A lot of modern dissertations are intended in a framework that allots with human security as an opponent to global security. Frequently, it is argued that the vary approaches and the perceptions to achieve the security have not only transformed significantly in recent times but have also obtained much stronger antagonism. The broader discussion on security look like to have grown to be iced-up in these two key approaches: first, the limited state related notion of security and second, the wider notion of security that is human centered. The apprehension is between these both referent objects - the state and people, between internal and external threats, military and non-military means to increase security. As long as this antagonism is being sustained in international policy orientation and academic analysis, the assumption may be short of sufficient perception for global security issues. 


\section{Critical View}

The critics believe (but see G Frerks and B Goldewijk, 2007) that human security is itself a confusing and highly challenged. It has aggravated huge criticism continually since it was incorporated in the United Nations Development Programme of 994. Some have debated that there is very small innovation in the human security dissertation since it significantly partly covers with the notions as human development and human rights. Others have criticized (but see G Frerks and B Goldewijk, 2007) the wider scope of human security that would decrease its logical sense. On the other hand some have pointed out the concern about the ambiguity of the notion, involving such a wide-range of threats that are impracticable to get matching in the policy making. The lack of conviction appeared regarding to realistic schemas because of its high level. These apprehensions have been expressed that it might be hard to precedence with the numerous issues. Accept this various multiple and complex explanations have came out in the human security debate, over and above much are theoretical disagreements.

Any debate of global security in a plural world must face the threats especially related with the international system: the World War - I, World War - II, the Cold War that finished in a rise of intra-state conflicts, the risk of nuclear warfare, the war on terror, the rising gap between poor and rich, and the disturbance of environmental degradation. A part from this history human beings have suffered of mass-slaughter, Hiroshima and Nagasaki, the Holocaust, the ethnic cleansing related with the Rwandan genocide, the Cambodian killing and the Yugoslavia. Ironically, such developments have added to the growth of a global norms setting that increasingly articulates a common humanity. This argues that human security and international security can not just be move towards as antagonistic and parallel. In practical such discussion transform continuously, interrelate, and endure normative power of multiple forces and forms of human agency.

No doubt that the accurate definition of human security has remained indefinable in academic and policy circles. There is no conformity on a particular meaning of human security and it is believed that no simple agreement will be establish in the near future. However in recent times there is a rising trend (E Newman and O Richmond 200) to assert its contestability, to assent that there is no commonly established definition and to concur that these circumstances are needed to be lengthened. The concept has got ground that the idea might be more effectual as an establishing structure that is pliable in the opinion of rising challenges than as a comprehensive meaning that is unavoidably exclusive. It is exactly the width of human security that appends strength to its political significance and sensible meaning.

\section{Conclusion}

Human security emerged as a subject of international political concern but has not been achieved sustainable global response that probably essential to the multifaceted social, economic, political, cultural, environmental and humanitarian challenges. It is proper time to increase need for understanding the significance of cultures, plus the renaissance of religious thoughts at global level. It has been explained (B Goldewijk, 2007) that how this progress is shifting the traditional dissertations of 'secularization' and the detachment of the state, connecting the state system of Westphalia as well as enveloping forms of dualism. Religions and cultures are extremely dominant today in assembling social forces that aspire at reaching compassionate forms of security at all levels, ranging from human security to global security.

The wideness of human security as illustrated by these thoughts transforms the center of attention of security from states to people which becomes more significant in this globalised and transformed world. It also moves the burden of giving security form sovereign-states alone to many actors, containing governmental, non governmental organizations and national and local communities. Human security hence proposes collective approach to the study of global security. Even though the notion that human security includes several threats to the lives of individuals is comparatively new, a variety of elements of human security are problems that have long been studied by different disciplines of natural and social sciences. All the policymakers, practitioners and academicians are familiar with issues such as environmental degradation, disease, and poverty. The framework of human security purely coins a collective approach to the wellbeing of people by accentuating the interrelatedness of these diverse problems. The move in awareness of security from merely state centric deliberations to elements that persuade people of states is perceptible in academic plus in policy spheres. Nevertheless, human security should assess consecutively as scientifically and systematically. No doubt there is a need for improved analysis, measurement and conceptualization of issues along with the elements connected to human security; in order to better integrate issues of human security into the security schema of states and international organizations. 


\section{End Notes}

[1]. Shahrbanou Tadjbakhsh and Anuradha Chenoy (2007) Human Security: Concepts and implications, New York: Routledge.

[2]. Barry Buzan, Ole Weaver, and Jaap De (997) Wilde Security: A New Framework for Analysis, Boulder: CO.: Lynne Rienner

[3]. Amartya Sen (999) Development as Freedom, Oxford: Oxford University Press.

[4]. David Chandler (2003) 'New Rights for Old? Cosmopolitan Citizenship and the Critique of State Sovereignty', Political Studies, Vol. 5, No. 2 .

[5]. R. Muggah and K. Krause (2006) 'A true measure of success? The discourse and practice of human security in Haiti' Whitehead Journal of Diplomacy and International Relations.

[6]. T. Owen (2004) 'Challenges and Opportunities for Defining and Measuring Human Security', available at:http://www.hegoa.ehu.es/dossierra/seguridad/Challenges_and_opportunities_for_defining_and_measuring_hum.pdf

[7]. Human Development Report (994) New dimensions of human security, available at: http://hdr.undp.org/en/media/hdr_994_en_chap2.pdf

[8]. Human Development Report (994) New dimensions of human security, available at: http://hdr.undp.org/en/media/hdr 994 en chap2.pdf

[9]. Commission on Human Security Report (2003) Human Security Now, available at: http://www.unocha.org/humansecurity/humansecurity-now

[10]. Commission on Human Security Report (2003) Human Security Now, available at: http://www.unocha.org/humansecurity/humansecurity-now

[11]. Mahbub Ul Haq (999) Reflections on Human Development, Oxford: Oxford University Press.

[12]. Thakur Manab Thakur (997) International Management: Concepts and Cases, Delhi: Tata McGraw Hill Publication Company Limited.

[13]. Amartya Sen (2000) Freedom, Rationality, and Social Choice, Oxford: Oxford University Press

[14]. Robert Grant McRae (2002) Human Security and the New Diplomacy: Protecting People, Promoting Peace, Canada: McGillQueen's Press.

[15]. Commission on Human Security Report (2003) United Nations Office for the Coordination of Humanitarian Affairs available at: http://www.unocha.org/humansecurity/chs/

[16]. Georg Frerks and Berma Klein Goldewijk (2007) Human Security and International Insecurity, Netherlands: Wageningen Academic Publication.

[17]. Georg Frerks and Berma Klein Goldewijk (2007) Human Security and International Insecurity, Netherlands: Wageningen Academic Publication.

[18]. Georg Frerks and Berma Klein Goldewijk (2007) Human Security and International Insecurity, Netherlands: Wageningen Academic Publication.

[19]. Edward Newman and Oliver P. Richmond (200) The United Nations and Human Security, UK: Palgrave Macmillan

[20]. Berma Klein Goldewijk (2007) New Wars and the State: The Nexus Religion-Human Security, Human Security and International Insecurity, Wageningen: Wageningen Academic Publishers. 